\title{
A critical discourse analysis of the Pakistani newspaper headlines on the federal budget for FY 2021-2022
}

\author{
Muhammad Arshad*1 | Nazish Khan ${ }^{2}$ \\ 1. Department of English, Govt. Graduate College Bahawalnagar, Punjab, Pakistan. \\ 2. Daanish School Girls Campus, Rahim Yar Khan, Punjab, Pakistan. \\ *Corresponding Author Email: arshad.gcbwn@gmail.com
}

Published: October 21, 2021

\begin{abstract}
This research study is based on the Critical Discourse Analysis (CDA) of news headlines of different Urdu and English newspapers on the federal Pakistani budget for the fiscal year 20212022. This research is descriptive qualitative in its nature. Fairclough (1995a) model of three dimensions (text, discourse and social practice) was used to analyse text. 21 different headlines from renowned Pakistani national Urdu and English newspapers on June 12, 2021, were collected through purposive sampling techniques of data collection. The study highlights the concealed ideology of newspaper editors who aims to arouse masses by using stirring vocabulary. The significance of this study lies in the vocabulary of news items of newspapers headlines which serve as an important medium of presenting ideologies. Thematic and the linguistic analysis of newspaper headlines highlight those newspapers are concealed with important orientations for readers. The study draws the conclusion that news headlines represent editors' ideologies on their political inclinations and alignment in spite of their claim to be impartial. The newspaper editors exploit headlines to form a way of thinking on issues of national concern to achieve their political interests.
\end{abstract}

Keywords: critical discourse analysis, budget, newspaper headlines, Pakistani media, budget politics, media inclination, media discourse, language and ideology.

\section{How to Cite:}

Arshad, M. \& Khan, N. (2021). A critical discourse analysis of the Pakistani newspaper headlines on the federal budget for FY 2021-2022. Journal of Humanities, Social and Management Sciences (JHSMS), 2(1), 176-186. https://doi.org/10.47264/idea.jhsms/2.1.15

\section{Publisher's Note:}

IDEA PUBLISHERS (IDEA Journals Group) stands neutral regarding jurisdictional claims in the published maps and institutional affiliations.

Copyright: ( 2021 The Author(s), published by IDEA PUBLISHERS (IDEA Journals Group).

Licensing: This is an Open Access article published under the Creative Commons AttributionNonCommercial 4.0 International License (http://creativecommons.org/licenses/by-nc/4.0/) 


\section{Introduction}

Critical Discourse Analysis (CDA) is an area of research that has mapped the avenues for the researchers to uncover the covered ideologies behind the curtain of any discourse which apparently looks simple words in text or speech. As McGregor (2006) says that "our words are never neutral". According to Fiske (1994), our words have the power to reflect the interests of their speakers and that are never neutral. News headlines are tools providing great information to those who find difficult to read the full articles, and stories due to shortage of time (Taiwo, 2007). The role of newspapers is very significant in highlighting social issues according to their own ideology.

In Pakistan, the government presents the state budget for the next fiscal year during the months of May and June in Parliament. It is discussed and examined in parliament before getting approved and implemented. This budget always arouses hot debate in Pakistani media. Newspapers are full of article on budget. Every year, when the budget is presented in the Parliament of Pakistan, the very next day newspapers give full coverage to budget by coming up with main headlines on budget.

The present study is aimed at exploring the implied meanings and objectives of seemingly simple statements by the editors of newspapers in news headlines. For this study, the researchers have selected CDA of newspaper headlines on the federal budget of Pakistan for the financial year 2021-2022 announced in parliament on $11^{\text {th }}$ June 2021. According to Fowler (1991, p. 8), "I am not gunning for the (media)". The fundamental object of this research study is to unveil the various ideologies that are projected in different news articles on federal budget by examining the structure of selected newspaper headlines to elaborate the relation between structure and meaning.

\section{Literature review}

The term "discourse" denotes anything in written or spoken form in the usual usage of language. CDA is an area of investigation which has given an insight to linguists to uncover the concealed ideologies aberrantly covered by plain and common words. CDA aims at helping researchers to navigate the hidden ideologies that are rampant in have their own identity in society. It presents the concepts of discourse analysis in order to find out the power domination that influences the discourse. CDA focuses on how language exercises its power in the society as Van Dijk (1996, p. 86), points out, "one of the central tasks of CDA is to account for the relationships between discourse and social power". CDA researchers postulate that language wields enormous influence in both written and spoken discourse. CDA analysis reflects the facts when examined with a micro-eye. It also studies dynamics of language in a given society. Van Dijk (2001, p. 352) says, "CDA is a type of discourse analytical research that primarily studies the way social power abuse, dominance, and inequality are enacted, reproduced, and resisted by text and talk in the social and political context". Fairclough and Wodak (1997) emphasize that CDA performs ideological work.

\subsection{Discourse of media}

Few of us are completely unaffected by the media. The impact of media on the modern world is undeniable because discourse is so important in establishing people's beliefs. Public pinions 
A critical discourse analysis of the Pakistani newspaper headlines on the federal budget ...

and beliefs are always mould by media institutions (Herman \& Chomsky, 2002). The field of media discourse is multidisciplinary. Beside extensive interest of media and culture studies, it has great interest in CDA. In every society media has infinite importance. Richardson (2006, p. 6) explains that the role of journalism is to "enable citizens better understand their lives and their position(s) in the world" Media has the ability to determine how beliefs are presented to audiences and perpetuated. As Fairclough (2003, p. 53) explains further, "when the voice of another is incorporated into a text, there are always choices about how to 'frame' it, how to contextualize it in terms of other parts of the text". Daily newspapers published in the same country always speak in diverse voices, addressing a variety of imagined audiences defined by geography, socioeconomic groups, political perspectives, and other considerations.

News has been defined differently by different research scholars. Van Dijk (1988b; 1993) suggests that news is a text or discourse on Television and radio, or in the newspapers presenting new information about current incident or situation. However, Fowler (1991) explains that news is a product formed due to political, economic or cultural factors. Many people get news by many sources like, television news programmes, radio, internet or social media. Newspapers are frequently read at work and during commutes to and from work. News items are debated, read out loud, and commented on in various work and home settings, allowing readers and newspapers to negotiate the meanings of news. Newspapers are frequently read at work and during commutes to and from work. News items are debated, read out loud, and commented on in various work and home settings. Hence, the meanings of news are negotiated among readers and the newspapers. As stated by Reath (1998, p. 50) about media, "are not simply vehicles for delivering information. They guide the ideological stance of the reader."

\subsection{Language and ideology}

This research study has proposed the importance of ideology and the role of language in maintaining and reinforcing it in society. The term ideology has been defined variously and not in a unified way by research scholars. Literature on ideology presents a variety of definitions. According to Johnstone (2018) ideology is a system of beliefs. Hatim and Mason (1997, p. 218) describe ideology as, "a body of assumption which reflects the beliefs and interests of an individual, a group of individuals and societal institutions which ultimately finds expression in language". Van Dijk (1988b, p.7) explains, "Ideologies are the fundamental beliefs of a group and its members".

According to Fairclough (Fairclough, 1995b, p. 56) discourse can be ideological in some way or the other, "Orders of discourse can be seen as one domain of potential cultural hegemony, with dominant groups struggling to assert and maintain particular structuring within and between them". Through language, ideology is frequently linked to politics, power, competing political parties and organizations, and, of course, conflicts. Taiwo (2007) argues that news reporters, editors and feature writers are more likely to work on societal ideals or world conceptions in order to develop media messages.

\subsection{Newspapers headlines}

Headlines reach considerably greater number of audience s compared to those who read the news articles because everyone who buys the newspaper might put a glance on the headlines. 
As soon as the newspaper seller display their newspapers at the stall, many people including passersby, get a chance to put a glance at the headlines. Later, these headlines are further discussed in at their home, workplace or any other domain. It is even more true to the headlines of front page which are selected with great care and concern to manifest specific ideology and excite some emotions among readers.

Furthermore, headlines are often glanced at public transport or stalls. According to Develotte and Rechniewski (2001), newspaper headlines are more likely to have a greater influence on readers because of some certain linguistic features. Moreover, according to Develotte and Rechniewski (2001) headlines are an abundant tool of gathering information about the field of cultural references. According to Taiwo (2007), headlines function as a forerunner to news reports. According to Reah (2002, p. 13), it is "a unique type of text that consists of a range of functions that specifically dictate its shape, content, and structure, and it operates within a range of restrictions that limit the freedom of the writer". They highlight the social and cultural representations existing in a society. Hence, newspaper editors deliberately adopt eye-catching expression.

The headline is the very first item to be read about the development of a news story. However, it is the last item to be written (Bell, 1991). In this way, news publishers find opportunity to express their ideology directly through it. Headlines are framed attractively to bring the reader's attention to the subject being discussed. Whereas Morrish (2003) explains that headlines are the final gist of news articles. Reader's level of interest decides his willingness to carry on reading the news article.

\section{Theoretical framework}

For the past two decades, research on the discourse analysis of media within the paradigm of CDA has placed the media as an establishment which serves as the social and discursive institution. Several studies on news analysis have been undertaken, including studies on linguistic analysis of news discourse and language. Researchers whose work has had a notable impact on the development of CDA are Van Dijk (1985), Fairclough (1995a), Paniagua et al. (2007), Fowler (1991), Bell (1991), Richardson (2007), Bell \& Peter (1998), Matheson (2005), Lukin (2013) and Boyd-Barrett (2009).

This study uses a CDA model developed by Norman Fairclough which attempts to construct a discourse analysis model that offers a social and cultural analysis, combining the heritage of textual analysis. This model examines language in a contained space, with the context of the larger community. Fairclough is interested in considering language as a form of power. Fairclough (1995a) built a model that integrates discourse analysis based on linguistics, social thought, politics, and generally integrated into social change. Hence, the model proposed by Fairclough is often considered as a model of social change.

The use of language is referred by Fairclough (1995a) as a social practice instead of an individual action or reflection when he applies the term discourse. The concept of language as a social practice has a number of aspects. Firstly, discourse is a type of action in which someone employs language to perform an action on the world, specifically as a sort of representation when observing the world or reality. Second, this approach recognizes that discourse and social structure are closely intertwined. 
A critical discourse analysis of the Pakistani newspaper headlines on the federal budget ...

Figure 1: Three dimensional CDA framework (Fairclough, 1995a, p. 59)

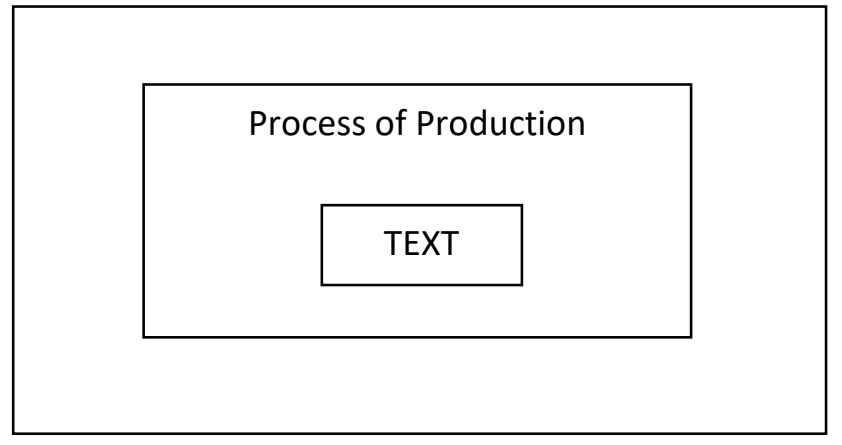

Fairclough (1995a) tries to divide discourse analysis into three main dimensions: text, discourse practice, and social practice. In 'text dimension', the analysis of text is made linguistically, by analysing vocabulary, semantics, and sentence order. He also incorporated coherence and cohesiveness, which refers to how words or sentences fit together to make a coherent whole. The second dimension of the model is the 'discursive practice' which involves the production and use of texts. The third dimension is a 'social practice' based on wide social goals and cultural practices.

According to Fairclough (1995a), journalists, media audiences, and public participants are the three main types of participants in the media. In terms of text production, the news primarily involves two parties: news readers and journalists. The third and final dimension of Fairclough's (1995a) model is discourse as "social practice," which combines ideology, power, and hegemony to show how discourse can reproduce or transform unequal power relations. As a result, analysing this dimension in the newspaper, particularly in hot topics, necessitates looking beyond the text and examining the relationship between journalism and ideology formation (Richardson, 2007).

\section{Methodology}

This research study applies a comprehensive methodology to maintain reliability and validity. Present research is descriptive qualitative in its nature that investigates ideological basis in Pakistani newspapers headlines to determine their influence on the readers. The data used for this study was gathered from a variety of Pakistani Urdu and English newspapers. However, headlines of the newspapers on Pakistani Federal Budget for the fiscal year 2021-2022, is the only source of data collection. Data was collected by using purposive sampling techniques of data collection for present research study. The purpose of this research study is to trace out how different newspapers in Pakistan dealt same topic differently, projecting their hidden ideology and political alignment. So, the study is an attempt to explore their concealed ideologies by following Fairclough's (1995a) framework of CDA that focuses on textual analysis, considering the variables of lexical choices, cohesion, style, bias, and rhetoric in the newspaper's headlines on Pakistani budget for FY 2021-2022.

\section{Data analysis and discussion}

For this study, data was gathered from 21 Pakistani newspapers. The purpose of this study is to investigate different manifestations of the same national issue of Pakistani federal budget 
for the fiscal year 2021-2022, thematically and linguistically. It would also probe into different perspectives newspapers with some political alignments. Nine news headlines of English newspapers and 12 news headlines of Urdu newspapers were collected, about Pakistani state budget FY2021-2022 presented in the Parliament of Pakistan on $11^{\text {th }}$ June 2021. Some procedures that the research adopted are firstly, the researchers collected data (newspaper headlines), proceed for critical analysis, and as a result developed a theory. Secondly, the researchers identified the newspaper headlines by using CDA. The CDA analysis of these news headlines depicts how the same news is presented to native and foreign readers.

\subsection{Urdu newspaper headlines}

The headlines of Urdu newspaper reflect the same issue of state budget which has been dealt in different manner. Word choice in Urdu newspaper is also different. As Fowler (1991) asserts that there are many ways of telling the same thing. This difference of expression carries different ideology and different representation.

- Tankhaon, pension main izafa, cheeni cigarette, luxury ashya mehmgi (Roznama Jang)

- Tankhah, pension main 10 fesad izafa, chotoi garian, ghee sasta, tire, batterian, mobile callen mehngi (Roznama Express)

- Tankhaon, pension main 10 fesad izafa, cheeni, calls, mobile phones mehngy, chotoi garian, tractor, ghee, kitaben sasti (Nawaye Waqt)

- Tankhaon or pension main izafa: chotoi garian, khurdni tail, ghee sasta, phones, calls, internet mehmga (Roznna Pakistan)

- Chotoi garian, tractor, ghee, kitaaben sasten, ghair mulki mobile, tire, make up ka saman mehnga (Duniya Lahore)

- Tankhaon, pension main 10 fesad izafa, texon men kami, zarae machinery, mobile, chotoi garian sasti (Roznama Khabren)

- Pension, Tankhah 10 fesad izafa: dawaen, tibi alaat, electric wa choti garian, food supplements sasty (Roznama Osaaf)

- 8 khrab 487 arab ka budget, takreban pony 4 kharab khasara ho ga (Roznama Jasaarat)

- Tankhah, pension main 10 fesad izafa, mobile calls internet mehnga, chotoi wa electric garian sasti (Roznama Jinnah)

- Chotoi garian, murghe, khurdani tail sasta, calls, tires mehngy (Roznama Ummat)

- Tankhah, pension main 10 fesad izafa (Roznama Aaj)

- Tankhaon, pension main 10 fesad izafa (Roznama Mashriq)

We find that Urdu newspapers focus on 'increase in salary and pension' as shown above. All newspapers end with different words which highlight the editor's ideology. As Van Dijk (1988b, p. 11), asserts "media are not neutral, common sensed or rational mediator of social events, but essentially help reproduce performulated ideologies." News makers take interest in creating sensationalism as words in each headline depict, 'Tankhah/pension men 10 fesd izafa', 'gaarian susti, mobile and calls menhngy, internet mehnga', 'Mehngy', 'mehngi', 'susty' (10\% percent increase in pay and pension/ overpriced, inexpensive).

However, it is clear that the editors are well aware of the fundamental needs and desires of the people, and they exploit this situation because they think that people expect about increase in salary due to the high inflation rate and dearness in the country. So, headlines of Urdu 
A critical discourse analysis of the Pakistani newspaper headlines on the federal budget ...

newspaper focus on 'increase in salary and pension', 'tax', 'small cars', 'internet', 'mobiles', 'calls', 'cigarette', 'ghee', 'tractors', 'sugar', 'books', 'edible oil' and 'medicines.'

Selection and use of vocabulary for headlines in Urdu newspapers is different than English newspapers. The reason is that Urdu newspaper readers and English newspaper reader do not belong to the same strata of society. There is difference of socio-economic status between these classes. Hence, they have different problems in everyday life. Therefore, editors excite public through different choice of words keeping the same agenda.

\subsection{Headlines of English newspaper}

In Pakistan, it is supposed that English newspapers are read by the elite class of citizens. Hence, the same issue is treated differently but both the editors of Urdu and English newspapers supposed to have similar ideology. Newspaper editors work on societal values and develop their own beliefs and ideologies Taiwo (2007). Their ideology gets supported by the news headlines. That is why they frame such news headlines which make people gloomy. According to Taiwo (2004), the editors use headlines systematically and strategically. They chose rhetorical devices and sentimental words for readers. News headlines of English papers are presented as under:

- Govt on spending spree with third budget (The Dawn)

- Development, growth promised (The News)

- Rs.8.4tr 'relief, growth-oriented' budget (The Nation)

- Pro-growth, relief-oriented budget (Daily Times)

- Budget sets sights on growth (Express Tribune)

- $\quad$ PTI govt unveils Rs.8.5tr relief budget (Pakistan Observer)

- Govt tables Rs. 8.5tr budget for FY 21-22 (Pakistan Today)

- Growth- focused budget: IMF acquiescence, not consent? (Business Recorder)

- Trin unveils Rs. 8.487 billion budget (Regional Times)

The English newspapers headlines portray same ideology of editors who suggest that there is relief for the public in budget. Thus, most of the editors have used same phrase, 'growthfocused' which carry their ideology. Newspaper headlines arouse readers' interests and provoke emotions. For example, words such as "growth", "spending spree", "relief", "progrowth" serve the purpose of news editors. Almost all Urdu newspaper editors have used same phrase, 'tankhah, pension me izaafa'. This use of sentimental words makes a difference for the readers. Although English newspapers headlines vocabulary is different from Urdu newspapers, yet it performs the same function. English newspaper headlines also depict a sense of optimism.

\subsubsection{Linguistic features of newspaper headlines}

Newspapers also have some linguistics and grammatical characteristics. These characteristics include (1) subject and auxiliaries verb omission; (2) nominalizations; (3) passivization; (4) graphological Devices; (5) Use of Adjectives; (6) Figurative Information. Some of these linguistic features are discussed in the coming sections. 


\subsubsection{Omission of subjects and auxiliary verbs}

In English newspapers, auxiliary verbs have not been employed in news headlines. This is a common tactic in news headlines. News editors use this technique to produce phrases and sentences that have a strong impact on their readers. Same can also be seen in Urdu newspapers.

- Govt on spending spree with third budget (The Dawn)

- Development, growth promised (The News)

- Rs.8.4tr 'relief, growth-oriented' budget (The Nation)

- Pro-growth, relief-oriented budget (Daily Times)

- Growth- focused budget: IMF acquiescence, not consent? (Business Recorder)

- Tankhaon, pension main izafa, cheeni cigarette, luxury ashya mehmgi (Roznama Jang)

- Chotoi garian, murghe, khurdani tail sasta, calls, tires mehngy (RoznamaUmmat)

- Tankhaon, pension main 10 fesad izafa (Roznama Mashriq)

By using CDA devices, it is obvious that auxiliary verbs or helping verbs are omitted. This technique gives chance to the editors of news headlines to make short words. Critical Discourse Newspaper headlines analysis unveils the concealed ideologies of editors and newspaper owner. Hence, power is represented through such sentimental words. These emotions have no effect for editors, but they are meant for the public. This study shows that editors use language to exploit readers and to achieve their political goals.

Different studies show that there are many ways to express the same thing and ideology is represented in expressions. Ghannam (2011) also supports this statement by conducting research on ideology conveys by Lebanon newspapers. The overall findings of this study also reveal that the similar issue of the Pakistani federal budget for fiscal year 2021-2022 has been treated in differently. So, it is clear that choice of words is ideological contested. We also find that newspaper editors often grab readers' attention by using journalistic techniques.

\subsubsection{Nominalization}

The term nominalization means "turning verbs into nouns". However, Cook (2008, p. 66) describes, "nominalization is when actions and processes re-referred to by nouns as though they, rather than the people doing them, were the agent". This method turns action into impersonal and inevitable. This linguistic trait is highlighted in the following newspaper headlines:

- Development, growth promised (The News)

- Rs.8.4tr 'relief, growth-oriented' budget (The Nation)

- Pro-growth, relief-oriented budget (Daily Times)

- Govt tables Rs. 8.5tr budget for FY 21-22 (Pakistan Today)

- Growth- focused budget: IMF acquiescence, not consent? (Business Recorder)

- Tankhaon, pension main izafa, cheeni cigarette, luxury ashya mehmgi (Roznama Jang)

- Chotoi garian, murghe, khurdani tail sasta, calls, tires mehngy (Roznama Ummat)

- Tankhah, pension main 10 fesad izafa (Roznama Aaj)

- Tankhaon, pension main 10 fesad izafa (Roznama Mashriq) 
A critical discourse analysis of the Pakistani newspaper headlines on the federal budget ...

\subsubsection{Passivization}

This is another very significant linguistic element of the newspaper headlines. The editors of newspapers employ this technique as they do not like to reveal responsible agents of their statements. In the above newspaper headlines except four i.e. "Govt on spending spree with third budget 'PTI govt unveils Rs.8.5t relief budget, Trin unveils Rs. 8.487 billion budget and GOVT TABLES RS8.5TR BUDGET FOR FY21-22”, responsible agents for the announcement of budget are hidden. In spite of this, the reader can respond and assess the budget in the same way.

\subsubsection{Graphological devices}

This is another technique used sometimes by the editors of the newspapers. The editors employ graphological devices to depict their hidden ideology. The editors use bolt upper case and bolt that represents such ideologies. For example: Govt tables Rs. 8.5tr budget for FY 21-22 (Pakistan Today).

Use of uppercase reflects that the editors wished to highlight that there is no new tax imposed on public. The editors made use of the bolt and uppercase to make readers see the issue in the same way as they presented it in headlines. In this way, readers' thoughts are revolutionized.

\subsubsection{Use of adjectives}

The editors also projected their ideology by using adjectives for the budget 2021-2022. Many adjectives have been employed by English newspaper editors, both in negative and positive manner which also reflect editors' hidden ideology. Some of the editors have used positive adjectives for the state budget because their slant is towards the government, and they projected it positively. 'Growth-oriented', 'relief- oriented', 'growth-focused', 'relief budget', 'growth promised' and 'susty (cheap)', are some of the terms used positively both English and Urdu newspapers editors.

Although English newspapers have not used adjective in negative way, yet some Urdu newspapers have used such adjectives to evoke sentiments among their readers. For example, 'phones, calls, internet mehnga (phones, calls, internet became sostly)', 'mehngy (expensive)', 'khasara (deficit)'; are adjectives which depict budget in a negative way.

\subsubsection{Figurative information}

Information is of key importance in news headlines. Thus, the headlines of the newspapers also carried statistical and figurative information on budget e.g., Rs.8.4tr 'relief, growth-oriented' budget, PTI govt unveils Rs.8.5t relief budget, Govt tables Rs. 8.5tr budget for FY 21-22, 'Trin unveils Rs. 8.487 billion budgets', ' 8 kharab 487 arab ka budget, takreban pony 4 kharab khasara ho ga'.

\section{Conclusion}

The CDA of newspaper headlines on the federal Pakistani budget reflect how ideology works in the construction of print media discourse. The findings of the study indicate how simple 
statements reveal editors' hidden beliefs behind simple statements. Editors frame the news in such a way to make the reader emotional against the current government, or to make them annoyed against certain political or religious figures. They construct headlines that have the ability to redefine and mould the audience's perceptions. The CDA has helped the researchers to discover these hidden ideologies. The study also shows that editors exploit headlines to form a way of thinking on issues of national concern. They present the same news in different perspectives to achieve their political interests. On the issue of budget, majority of newspapers headlines focused on 'no increase in salary' which projected invested interests of the editors and their management to make the salaried person emotional an annoyed. It is concluded that CDA needs to be applied to project the real picture behind the written words in the newspapers.

\section{References}

Bell, A., \& Peter, G. (Eds). (1998). Approaches to media discourse. Blackwell.

Bell, A. (1991). The language of news media. Blackwell.

Boyd-Barrett, O. (2009). Contra the journalism of complicity. Journalism, 10(3), 296-299. https://journals.sagepub.com/doi/10.1177/1464884909102588

Cook, G. (2008). Applied linguistics. Oxford University.

Develotte, C., \& Rechniewski, E. (2001). Discourse analysis of newspaper headlines: A methodological framework for research into national representations. Web Journal of French Media Studies,4(1), 1-12. http://wjfms.ncl.ac.uk/joed4.htm

Fairclough, N. (1995a). Media discourse. Edward Arnold.

Fairclough, N. (1995b). Critical discourse analysis. Longman.

Fairclough, N. (2003). Analysing discourse: Textual analysis for social research. Longman Group Limited.

Fairclough, N., \& Wodak, R. (1997). Critical discourse analysis. In T. Van-Dijk (Ed.), Discourse as social interaction (pp. 258-284). Sage Publications

Fiske, J. (1994). Media matters: Everyday culture and political change. University of Minnesota Press.

Fowler, R. (1991). Language in the news: Discourse and ideology in the press. Routledge.

Ghannam, N. (2011). Newspaper ideology: A critical discourse analysis of an event published in six Lebanese newspapers. M.A Dissertation, University of the Witwatersrand, South Africa.

Hatim, B. \& Mason, I. (1997). The translator as a communicator. Routledge.

Herman, E., \& Chomsky, N. (2002). Manufacturing consent. Pantheon.

Johnstone, B. (2018). Discourse analysis ( ${ }^{\text {rd }}$ Ed.). Blackwell.

Lukin, A. (2013). Journalism, ideology and linguistics: The paradox of Chomsky's linguistic legacy and his 'propaganda model'. Journalism. 14(1), 96-110. https://doi.org/10.1177\%2F1464884912442333

Matheson, D. (2005). Media discourses: Analysing media texts. Open University Press.

McGregor, L. T. (2006). Critical discourse analysis: A- Primer. http://www.kon.org/archives/forum/15-1/mcgregorcda

Morrish, J. (2003). Magazine editing: How to develop and manage a successful publication. Routledge.

Paniagua, J. M. B, López García, G., Sancho Cremades, P., Serra Alegre, E., Clark, C. M. D. B., Dirks, U., ... \& Guillamón Carrasco, S. (2007). Critical discourse analysis of media texts. https://roderic.uv.es/handle/10550/33478 
A critical discourse analysis of the Pakistani newspaper headlines on the federal budget ...

Reah, D. (2002). The language of newspapers ( $2^{\text {nd }}$ Ed.). Routledge

Reath, D. (1998). The language of newspapers. Routledge.

Richardson, J. E. (2007). Analysing newspaper: An approach from critical discourse analysis. Palgrave Macmillian.

Taiwo, R. (2004). Speech as headline in Nigerian newspapers. In Segun Awonusi, \& E. A. Babalola (Eds), The domestication of English in Nigeria (pp. 323-335). University of Lagos Press.

Taiwo, R. (2007). Language, ideology and power relations in Nigerian newspaper headlines. Nebula, 4(1), 218-224. https://www.researchgate.net/publication/26456692

Van Dijk, A. T. (ed.) (1985). Discourse and communication: New approaches to the analysis of mass media discourse and communication. Walter de Gruyter.

Van Dijk, T. A. (1988a). News analysis. Case studies of international and national news in the press. Erlbaum

Van Dijk, T. A. (1988b). News analysis. Erlbaum.

Van Dijk, T. A. (1993). Principles of critical discourse analysis. Discourse and Society. 4(2), 249-283. https://doi.org/10.1177/0957926593004002006

Van Dijk, T.A. (1996). Discourse, power and access. In C. R. Caldas-Coulthard, \& M. Coulthard (Eds.), Texts and Practices: Reading in Critical Discourse Analysis (pp. 84-104). Routlegde.

Van Dijk, T.A. (2001). Critical discourse analysis. In D. Schiffrin, D. Tannen, \& H. E. Hamilton (Eds.), Handbook of discourse analysis (pp. 352-371). Blackwell. 